Guda A. I. ${ }^{1}$, Mikhalyov A. I. ${ }^{2}$

${ }^{1} \mathrm{PhD}$, Associate Professor, Associate Professor of Department of Information Technology and Systems, National Metallurgical Academy of Ukraine (NMetAU), Dnipro, Ukraine

${ }^{2}$ Dr.Sc., Professor, Chief of Department of Information Technology and Systems, National Metallurgical Academy of Ukraine (NMetAU), Dnipro, Ukraine

\title{
MULTI-MODELS IDENTIFICATION METHODS COMPARISON IN THE NON-LINEAR DYNAMIC SYSTEM IDENTIFICATION TASK
}

In this article a couple of identification methods for non-linear (possibly chaotic) dynamic systems are under consideration. Advantages and drawbacks of existent methods are mentioned. All methods under consideration make use a number of models. Different tactics for the models parameter movement for identification task solving are proposed. The simplest tactic uses models with fixed parameters. This method have simple realization, provide best identification speed and worst accuracy. Method with band-limited models allows us achieve better accuracy due to each model moving to its local extremum, but suffers to high-frequency oscillation, due to ignorance of the identification system dynamic itself. Approach with models, which movement simulates body movement under external forces and viscous friction demonstrates minimal identification errors among with significant speed. Identification process simulations are conducted and conclusion are made. According to simulation results advantages are highlighted and drawbacks are studied. Conclusions allows to make correct choice in identification method selection task. Also the results allows us to correctly chose some parameters on the identification system.

Keywords: non-linear dynamic system identification, multi-model identification methods, models ensemble, simulation, extemum estimation.

\section{NOMENCLATURE}

$n$ is number of models (not counting fake models);

$p$ is parameter value in general;

$p_{o}$ is parameter value for object

$p_{m i}$ is parameter value for model number $i$

$p_{0}$ is initial object parameter value of the non-steady case;

$p_{m i, 0}$ is initial parameter value of the model number $i$;

$p_{c}$ is parameter value of the current (or "central") model;

$p_{l}$ is parameter value of the "left" model;

$p_{r}$ is parameter value of the "right" model;

$\tilde{p}$ is relative parameter value;

$p_{g e}$ is parameter value, estimated by the global COG approach;

$p_{l e}$ is parameter value, estimated by the local COG approach;

$p_{e e}$ is parameter value, estimated by the second-order approximation for the best point;

$x$ is object or model output;

$q$ is criterion value;

$q_{o}$ is criterion value for the object;

$q_{m i}$ is criterion value for the model number $i$;

$q$, is criterion scale coefficient;

$F$ is quality function in general;

$\widetilde{F}$ is relative quality function;

$e$ is identification error in general;

$e_{g e}$ is identification error for the global COG approach;

$e_{l e}$ is identification error for the local COG approach;

$e_{e e}$ is identification error for the second-order approximation for the best point;

$a_{q}$ is coefficient for linear part in the criterion model;

$a_{q m}$ is coefficient for non-linear part;

$a_{1}$ is first coefficient in parabolic approximation;

$a_{2}$ is second coefficient in parabolic approximation;

$U_{p}^{2}$ is parameter amplitude;

$\omega_{p}$ is parameter frequency;

$f_{c}$ is attracting "force" to the center of band; $f_{n}$ is "force" due to interacting with neighbor models;

$f_{e}$ is attracting "force" to the estimated local extremum;

$f_{t}$ is total "force";

$k_{c}$ is coefficient for the $f_{c}$;

$k_{n}$ is coefficient for the $f_{n}$;

$k_{e}^{n}$ is coefficient for the $f_{e}$;

$v_{f}$ is coefficient for the "viscous" resistance.

\section{INTRODUCTION}

Identification of the complex non-linear dynamic systems, in particular, systems with chaotic dynamic [1], systems with dry friction in most cases is a formidable and non-trivial task. Even simple nonlinear systems may demonstrate complex, even chaotic behavior [2]. Some known methods can be applied in this area, but, obviously, the is no common solution due to non-constrained properties of such systems. Existent identification methods mainly use one model or pair of models, which significantly decreases identification speed and increases probability of mis-identification due to possible multi-extremum quality function shape.

So, the actual problem is to create new approaches to nonlinear (possibly chaotic) dynamic systems identification, which uses advantages of multi-model approach, investigate its properties, compare these methods under same conditions to provide background to select the proper one.

\section{PROBLEM STATEMENT}

Let's consider an object under identification with a parameter $p_{o}(t)$, and a set of models, with parameters $p_{m i}(t)$, $i=0 \ldots n-1$. We observe output signal $x(t)$ both from object (with particular measurement error) and from every of models. According to selected identification criterion, we measure or calculate corresponding criterions: $q_{o}(t)$ and $q_{m i}(t)$. Then, this signals from models compared (according to given scale $q_{\gamma}$ ) with object to form quality functions $F_{i}(t)$.

The task of identification in this condition is to find one model with corresponding parameter value $p_{e}$, which maximizes quality function. Moreover, all models from the 
set must provide behavior (it the sense of $p_{m i}(t)$ dynamics), which provide fast and precise identification in the given conditions. To achieve this task, models may exchange among itself information about current parameter value and quality function.

\section{REVIEW OF THE LITERATURE}

There is a great amount of developed method to solve identification task. First of all, we must mention well-known classical methods [3, 4]. This method have outstanding mathematical background, but in the case of complex (and chaotic) dynamic systems became inapplicable, as we cannot provide the required information about objects and satisfy numerous limitations.

Some modern approaches provide solution for more complex task - structural identification [5]. But, after investigation, this methods appears to limiting to the supported systems set, and appears vulnerable to the measurement noise.

Particularly to the chaotic systems, there exists a couple of method, based on the phenomena of the chaotic synchronization [6]. This methods prove its ability to deal with chaotic systems, but also have some drawbacks. First of all, synchronization is possible not only for one-to-one parameter confidence, but for other conditions due to nonlinear object properties.

One of the most useful adaptive-searching identification methods [8], in case of adequate criterion is provided [9], can be successfully used for this purpose. But, in general, this methods also have some drawbacks. First of all, this methods spend too much time to locate criterion extremum. Other essential drawback - measurement near one point decreases probability of identification in case of multiextremum criterion shape. Some methods [10, 11] demonstrates applicability of multi-model approaches to non-linear and chaotic system identification, but further investigations in this area are required.

\section{MATERIALS AND METHODS}

To receive identification simulation results, which is independent of particular dynamic system properties, the model of identification error (or the identification criterion) is required. One of the reasons of accuracy loss assumed to be criterion non-symmetrical form. So, the model must have a uniformly controlled part, which describes such phenomena. In this paper one of the simple representation will be used:

$$
q\left(p_{o}, p_{m i}\right)=a_{q}\left(p_{o}-p_{m i}\right)+a_{q m}\left|p_{o}-p_{m i}\right|,
$$

where $p$-parameter, $q$-identification quality criterion, $a_{q}-$ sensitivity coefficient, $a_{q m}$ - coefficient for non-linear part. Index "o" designates object under identification, and index "mi" belongs to model number $i$. Alternative form for (1), with quadratic nonlinear part, appears inadequate in the situation with large parameter range.

Quality function $F$ will be represented by this way:

$$
F\left(q_{m i}\right)=\exp \left(-\frac{q_{m i}^{2}}{q_{\gamma}^{2}}\right),
$$

where $q_{\gamma}$ - coefficient, which defines sensitivity scale. This definition inapplicable in real identification tasks due to ignorance object identification quality. In task under consideration, we move coordinate system to achieve $q_{o}=$ 0 . This allows us to control and investigate asymmetrical properties of the criterion uniformly in any parameter space part. Usage of definitions (1) and (2) ignores real system dynamic, interaction between object and model outputs, and make attempt to describe all object properties by 2 coefficients. This simplification give us opportunity to determine common properties of identification system itself. We assume, that dynamic properties on identification system is much "slower", then in non-linear system under consideration. In real systems this requirement is met in most cases.

One of the tasks, which appears while using multiple models, is the method to convert models parameter and criterion values to the final parameter value. The first approach consist in fuzzy logic "centre of gravity" (COG) approach:

$$
p_{g e}=\frac{\sum_{i=0}^{n-1} F_{m i} p_{m i}}{\sum_{i=0}^{n-1} F_{m i}}
$$

One obvious drawback is non-uniform usage of models at bounds, namely number 0 and number $(n-1)$. As a countermeasure of we add 2 fake fixed "out of band" models. This fake models will be designated by indexes " $l l$ " and " $r r$ ". Initial parameter values distribution on working area (and some behind) is uniform. Identification criterion for fake models assumed to be zero.

Calculation of $p_{g e}$ value is quite simple, but in case of multi-extremum criterion shape, or relatively large $q_{\gamma}$ value, the influence of the models, which is far from real extremum, may be significant. To drop such influence, we define value of similar value $p_{l e}$. which is bound to better point. Let $c$ (center) - index of model with maximum $F$. And $l=c-1$, $r=c+1$. Thus:

$$
p_{l e}=\frac{F_{l} p_{l}+F_{c} p_{c}+F_{r} p_{r}}{F_{l}+F_{c}+F_{r}} .
$$

Another way to determine extremum point in the range of 3 adjutant models is to approximate $F(p)$ by parabolic function. To simplify calculations, we shift the origin to the point $\left(p_{c}, F_{c}\right): \tilde{p}=p-p_{c}, \widetilde{F}=F-F_{c}$. Using this definitions, we receive:

$$
\begin{aligned}
& \left\{\begin{array}{l}
a_{2} \widetilde{p}_{l}^{2}+a_{1} \widetilde{p}_{l}=\widetilde{F}_{l} \\
a_{2} \widetilde{p}_{r}^{2}+a_{1} \widetilde{p}_{r}=\widetilde{F}_{r}
\end{array},\right. \\
& a_{1}=\frac{\widetilde{F}_{r} \tilde{p}_{l}^{2}-\widetilde{F}_{l} \tilde{p}_{r}^{2}}{\widetilde{p}_{l}^{2} \widetilde{p}_{r}+\widetilde{p}_{l} \tilde{p}_{r}^{2}}, \\
& a_{2}=\frac{\widetilde{F}_{r} \tilde{p}_{l}-\widetilde{F}_{l} \tilde{p}_{r}}{\tilde{p}_{l}^{2} \tilde{p}_{r}+\tilde{p}_{l} \tilde{p}_{r}^{2}}, \\
& p_{e}=p_{c}-\frac{a_{1}}{2 a_{2}} .
\end{aligned}
$$


This approximation is adequate only in regions with essential changes of quality function. Out of with regions equation (5) give results far from considered points triplet. To prevent displacement of $p_{e}$ out of band, defined by current 3 models, limit $p_{e}$ value to $\left(p_{l}, p_{r}\right)$. For practical reason, limitation may be stronger. If calculated by (5) extremum point is near to $p_{l}$ or $p_{r}$, then central point unlikely to be the best.

The value of $p_{e}$ where index " $c$ " means the best model, we define as $p_{e e}$. During simulation of identification process, we will observe $p_{g e}, p_{l e}$ and $p_{e e}$, along with corresponding identification errors:

$$
e_{g e}=p_{g e}-p_{o}, e_{l e}=p_{l e}-p_{o}, e_{e e}=p_{e e}-p_{o} .
$$

The identification quality will be estimated as standard deviation of identification error, measured at sufficiently large simulation time $T$.

\section{EXPERIMENTS}

The identification process simulation was conducted by developed simulation program "qontrol". Typical graphical representation of this program is represented in fig. 1.

During simulation process, criterion approximation, given by (1), was used instead of real or simulated dynamic objects. To check ability to identify non-steady systems, object parameter $p_{o}$ was given by one of 2 ways:

$$
p(t)=p_{0}+U_{p} \sin \left(\omega_{p} t\right)
$$

$$
p(t)=p_{0}+U_{p} \operatorname{sign} \sin \left(\omega_{p} t\right),
$$

where coefficients was set to values, which allows to test different modes: $U_{p}=40, \omega_{p}=1.1, p_{0}=45$. Working parameter range was given as $(0,100)$. Initial values of models parameter: $p_{l l}=-10, p_{m 0,0}=10, \ldots p_{m 4,0}=90, p_{r r}=110$. When the parameter changes is defined by the equation (7), it give us possibility to examine full parameter range covering. Otherwise, if the parameter value is given by the equation (8), dynamic properties and identification stability can be under investigation.

The values of other parameters was given as: $a_{q}=5$, $a_{q m}=0.5$. The value of $q_{\gamma}$ was changed in range $[2 ; 140]$. Standard deviations of identification errors was measured, and plots are provided for better values.

To satisfy this pager goals, three different approaches to locate quality function extremum, and, hence, the value of the parameter under identification is considered. First of all, a set of model with fixed parameters was under simulation. The second method allows every model to move in fixed band in the parameter space, and each model every simulation step adjust own parameter to the value, given by (5). The third approach also allows every model to move, but the current parameter value is given by the equation, which simulates body dynamic under action of some forces.

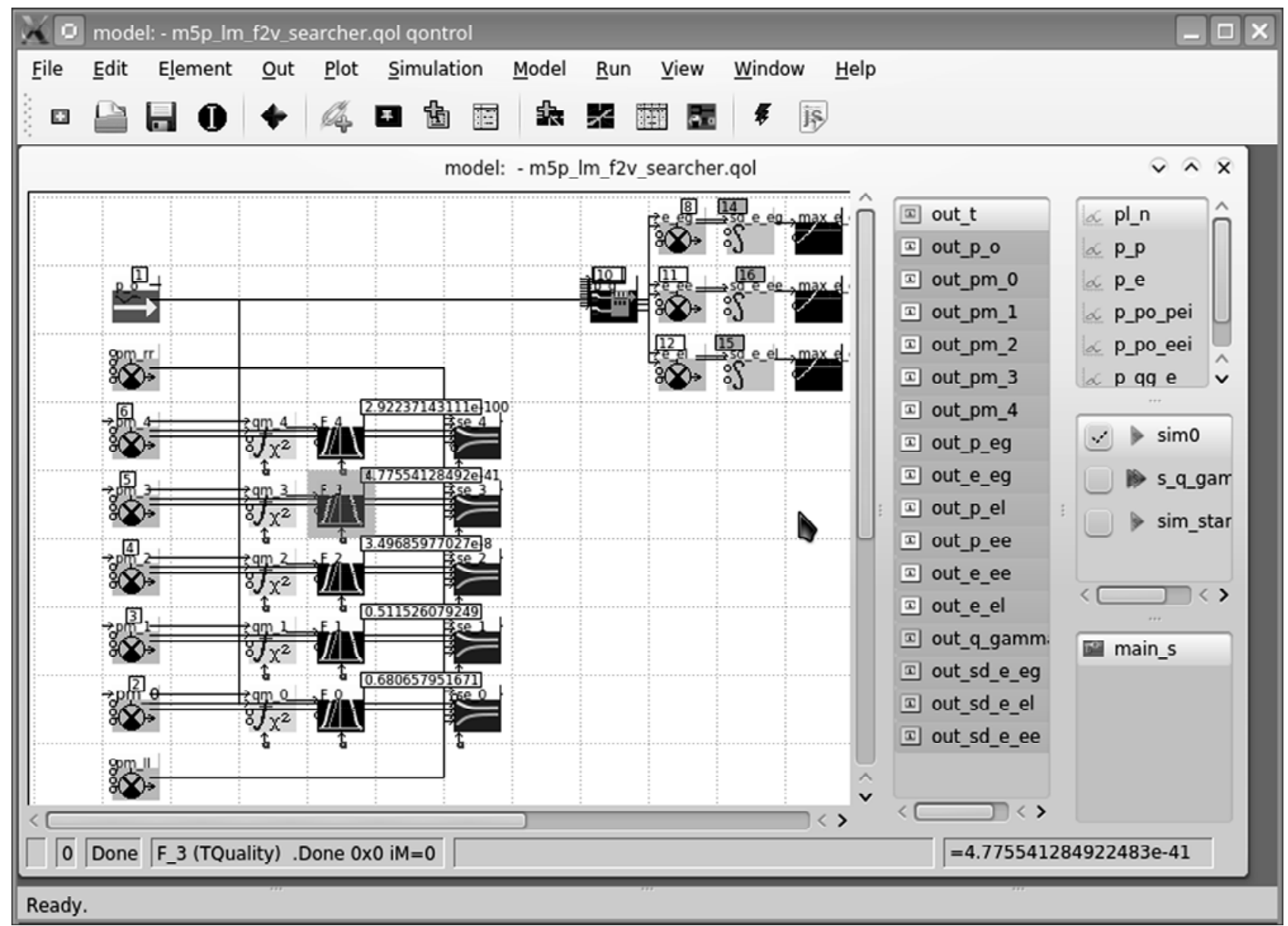

Figure 1 - "Qontrol" program main window 
For every of approaches, the identification process simulation was held, and the plots with every model parameter, object parameter and identification errors values are provided. Moreover, the dependence of the RMS errors from the quality function scale coefficient is shown.

\section{RESULTS}

In fig. 2 represented simulation results for identification system with fixed models with $n=5$ and $q_{\gamma}=60$. Object parameter behavior was given as (7) and (8). Fig. 3 represents identification errors.
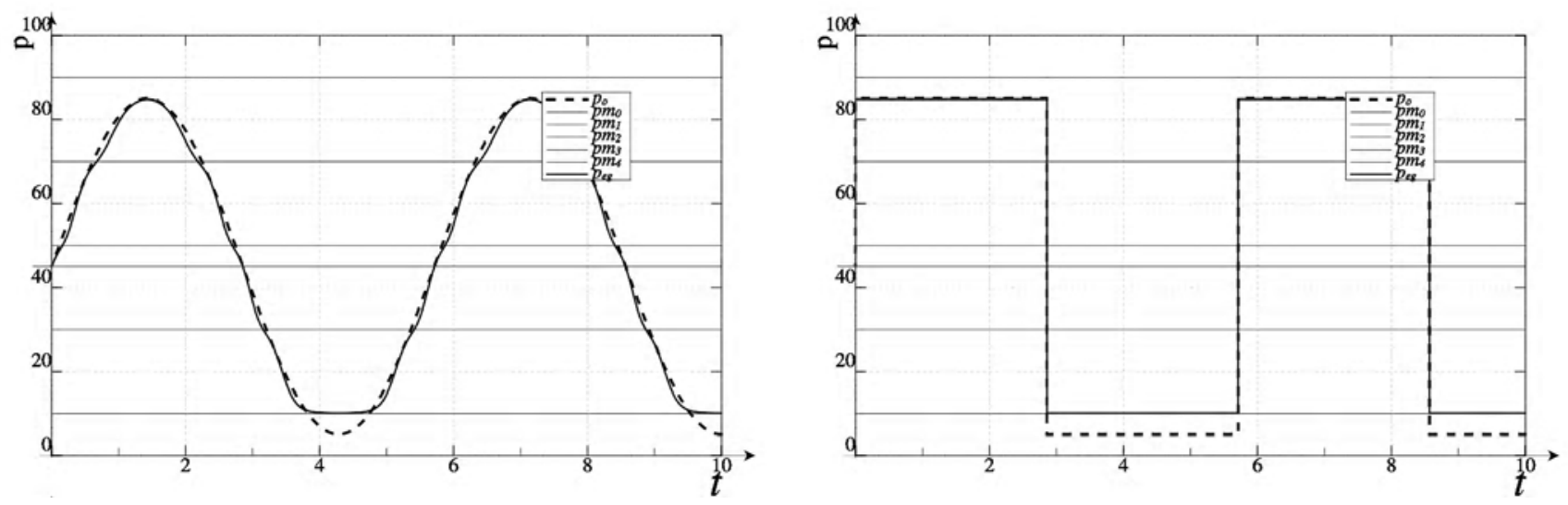

Figure 2 - Identification process with fixed models under conditions (7) and (8)
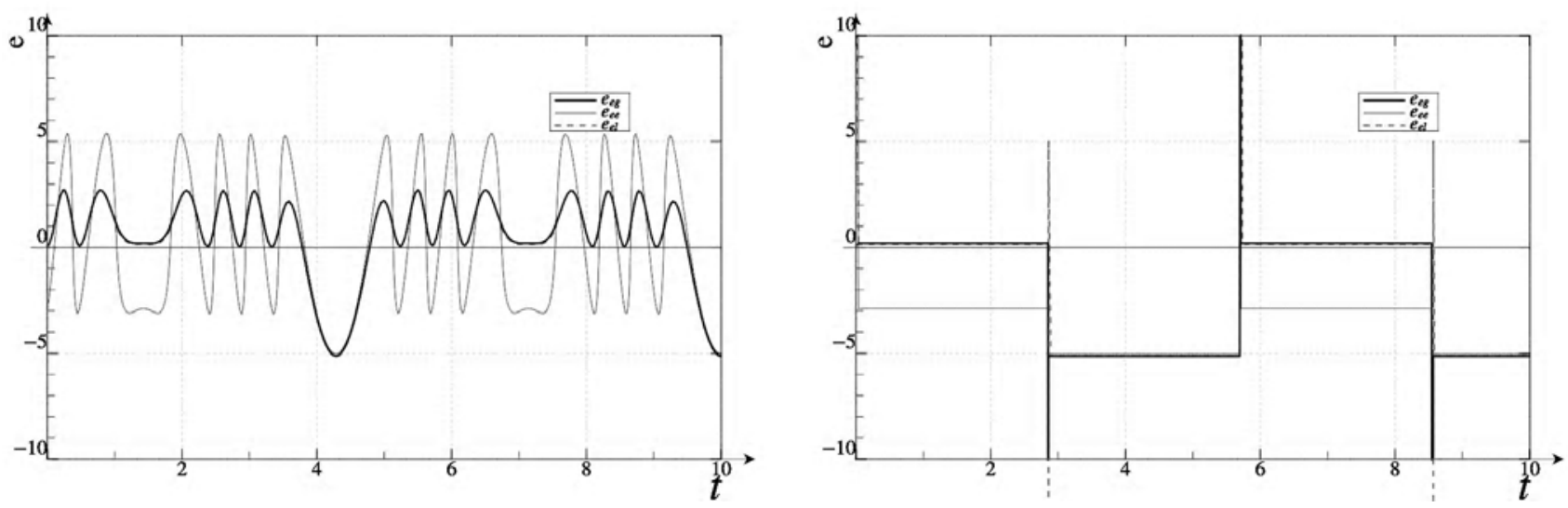

Figure 3 - The identification errors while identification with fixed models
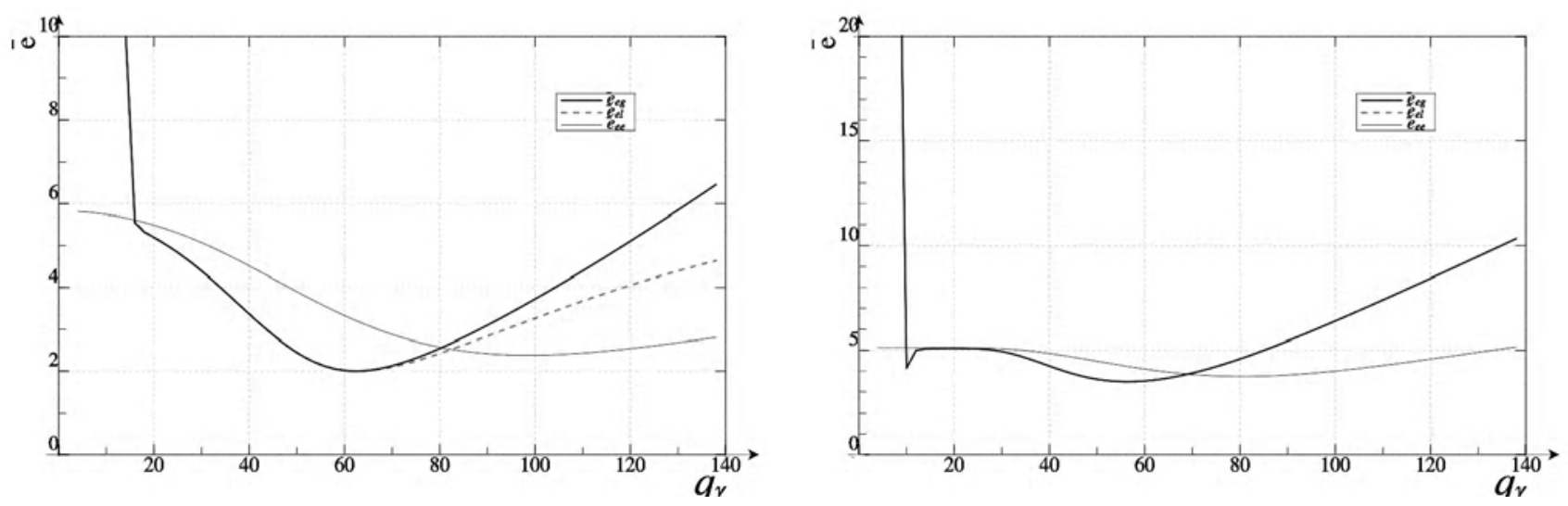

Figure 4 - RMS error dependencies from $q_{\gamma}$ while identification with fixed models under conditions (7) and (8) 

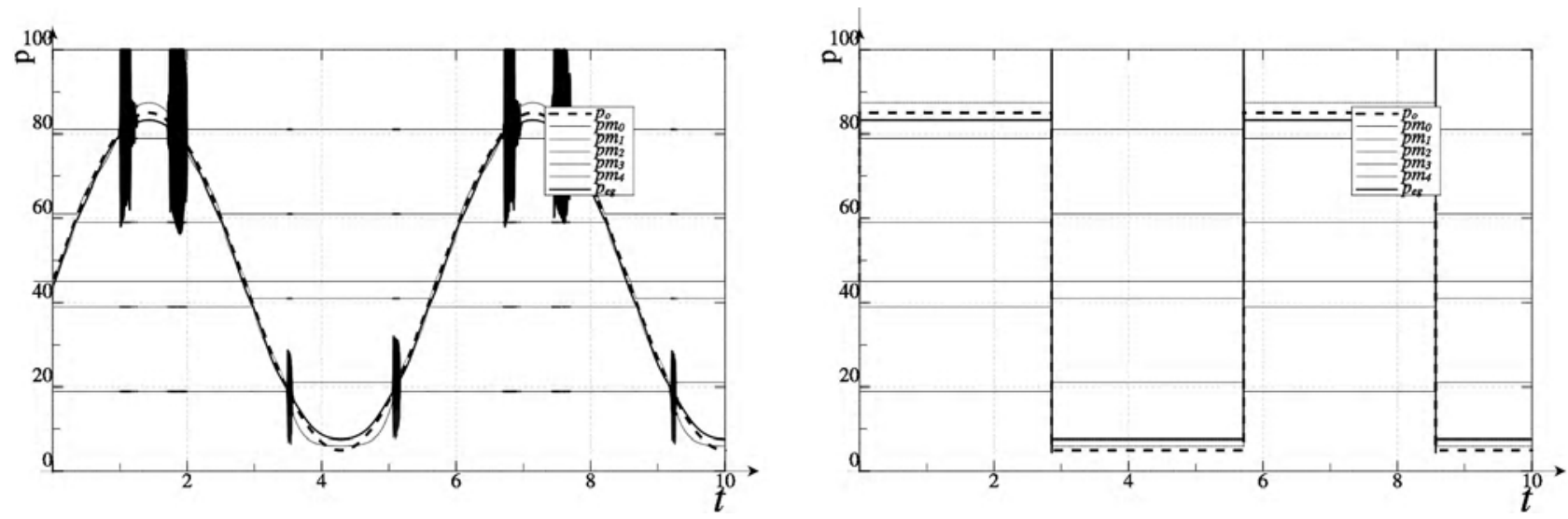

Figure 5 - Identification process with band-limited models under conditions (7) and (8)
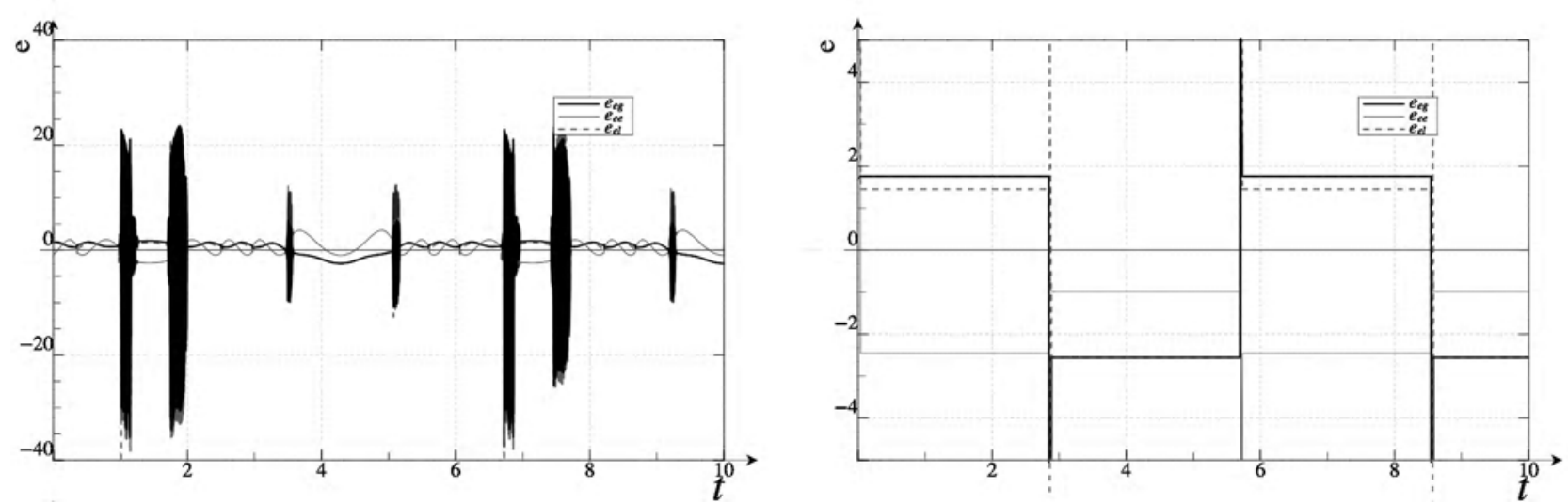

Figure 6 - The identification errors while identification with band-limited models
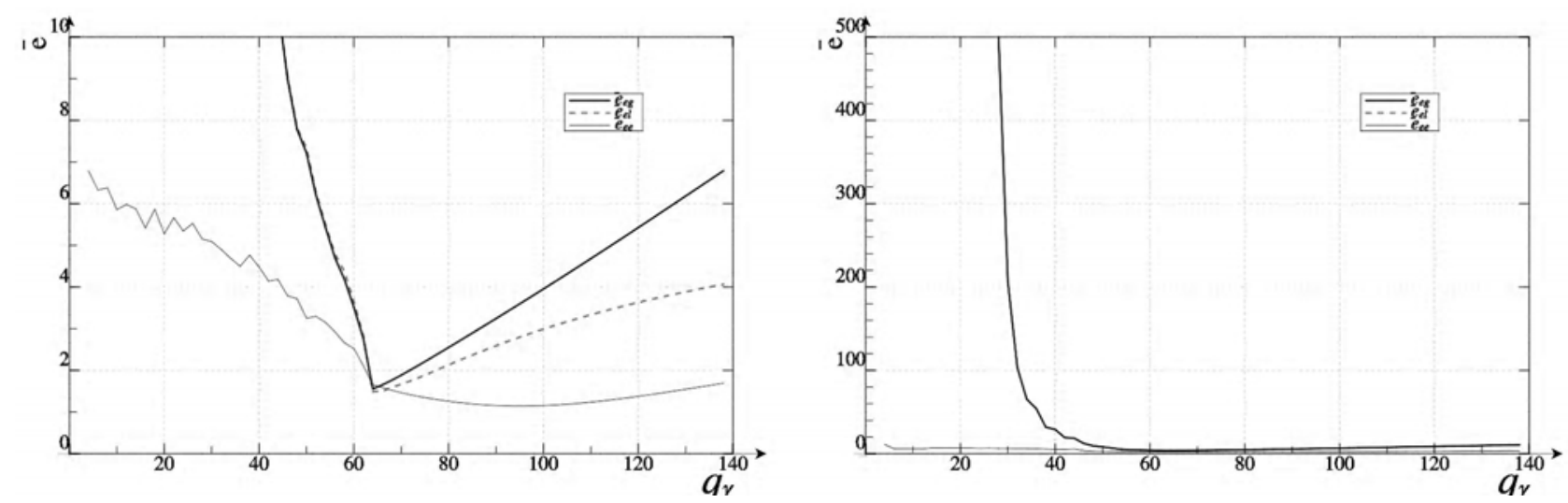

Figure 7 - RMS error dependencies from $q_{\gamma}$ while identification with band-limited models under conditions (7) and (8)

To achieve better results, we can treat every real model as physical body under influence of different forces. We investigate the influence of given "forces":

1. $f_{c}(t)=-k_{c}\left(p_{c}-p_{c, 0}\right)$ - "the attraction force" to the initial parameter value for current model. The presence of this force does not allow all models to take the same values near the extremum and thus stop the search process. It also allows to quickly switch to the other models in the case of a rapid change in the object parameter.

2. $f_{n}(t)=k_{n}\left(p_{r}-2 p_{c}+p_{l}\right)$ - "the force of interaction" with neighbours. It provides a more uniform distribution model parameters near the extreme.

3. $f_{e}(t)=-k_{c}\left(p_{c}-p_{e}\right)-$ "the force of attraction" to the local calculated extremum, which is given by expression (5).
Additional forces may be added, for example, to rise strong barriers between models, to prevent parameter confinement in certain conditions.

Net force $f_{t}(t)=f_{c}(t)+f_{n}(t)+f_{e}(t)$ may lead to model movement by different ways. In this paper the viscous approach is used:

$$
\frac{d p_{c}}{d t}=v_{f} f_{t}(t)
$$

where $v_{f}$ - proportionality factor (value, inversely proportional to viscous friction coefficient).

The simulation results are shown in fig. 8, 9. Used parameters: $k_{c}=1, k_{n}=1, k_{e}=5, v_{f}=2$. 

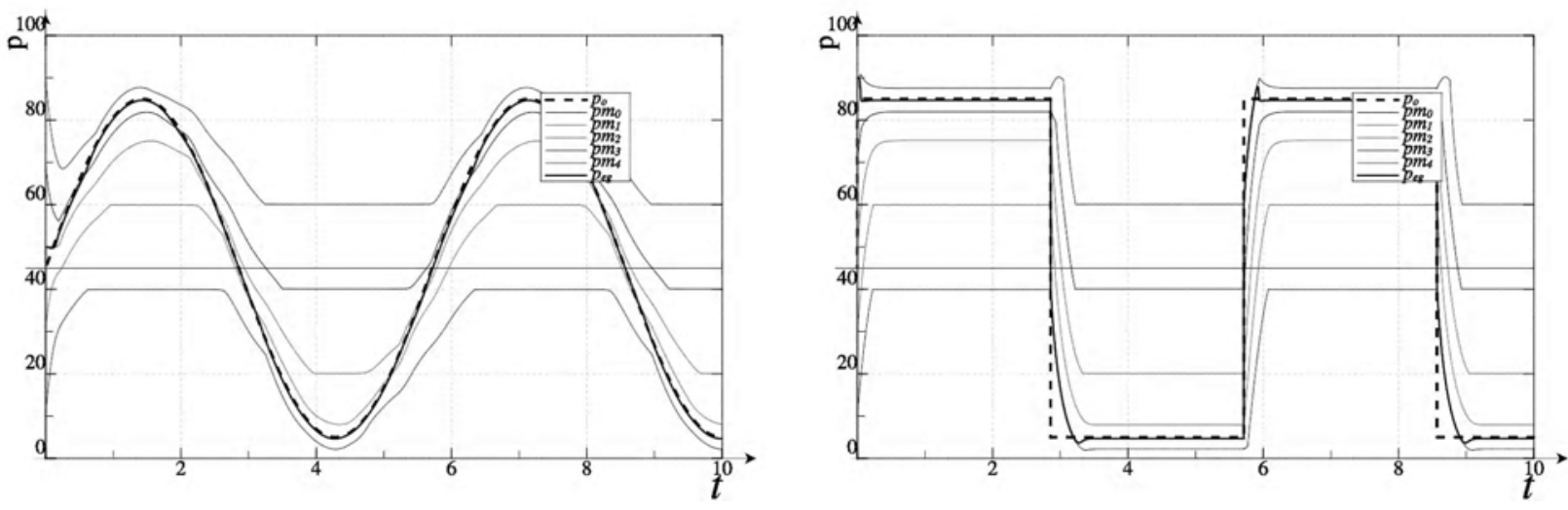

Figure 8 - Identification process with moving models (9) under conditions (7) and (8)
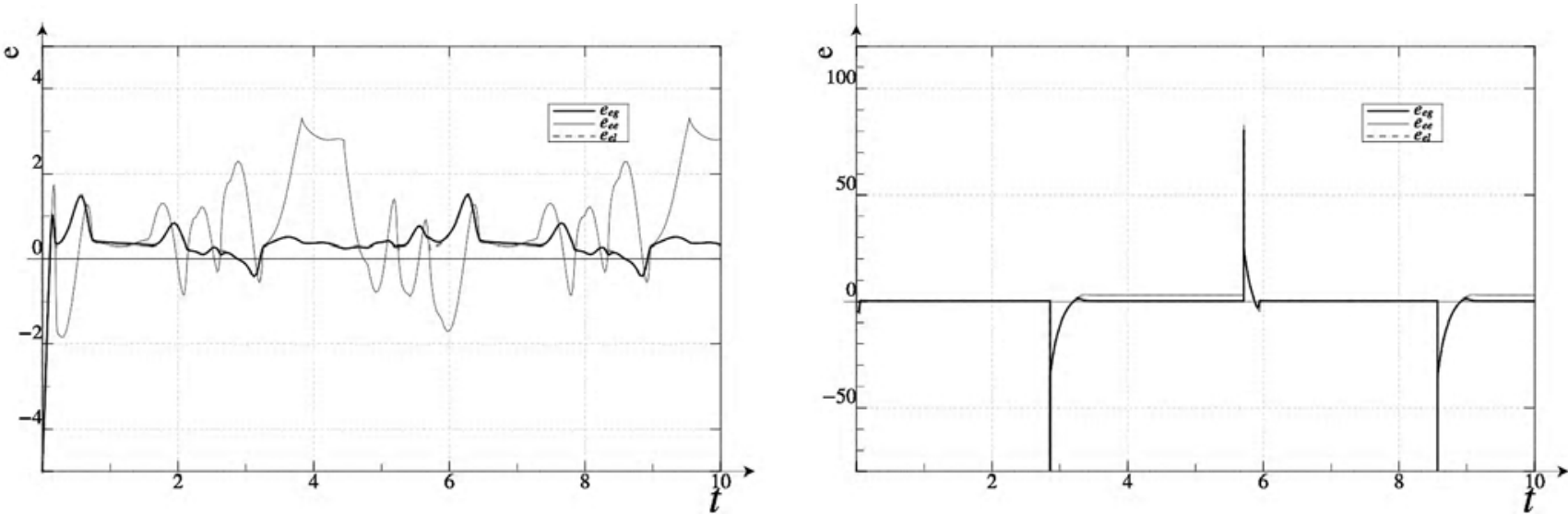

Figure 9 - The identification errors while identification with process with moving models (9) under conditions (7) and (8)
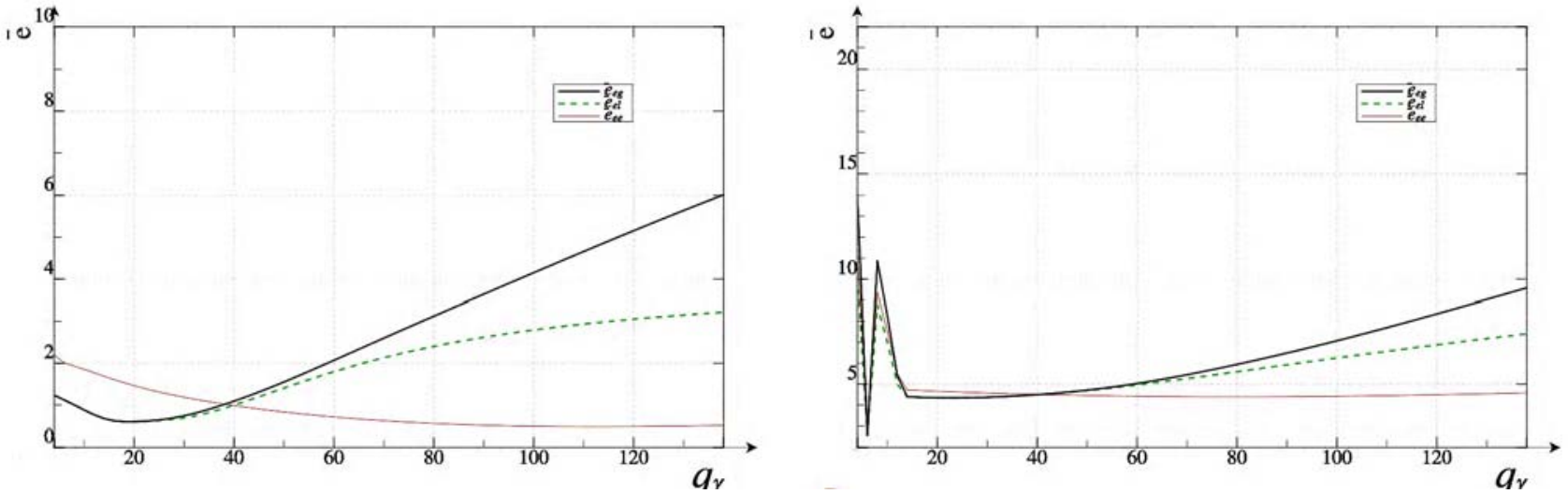

Figure 10 - RMS error dependencies from $q_{\gamma}$ while identification with moving models (9) under conditions (7) and (8)

\section{DISCUSSION}

The identification error analyses for the approach with fixed models shows (fig. 3), that this approach demonstrates maximal identification speed, which is determined only by the object dynamic itself. In this environment there is no visible difference between $p_{e g}$ and $p_{e l}$. Surprisingly, the values of $p_{e e}$ shows the worst results. Some of the possible reasons is considered in [12]. As predicted, error value is minimal near one of model parameters, and essentially increased near bounds. This approach demonstrates maximal identification speed, which is determined only by the object dynamic. In the current simulation conditions, identification occurs nearly instantaneous. As a consequence, essential identification error is observed. Also results shows, that for every method of parameter estimation, an optimal $q_{\gamma}$ value exists, and optimal $q_{\gamma}$ value for $\bar{e}_{e e}$ is essentially large, then for $\bar{e}_{g e}, \bar{e}_{l e}$.

The identification error analyses (fig. 7) for the approach with band-limited models shows, that, in general, this method leads to less errors under the same conditions, then method with fixed models. Moreover, due to moving parameters the are no "dead zones" near working range boundaries. One model is follows the object parameter in own band, and provides better identification results. 
The error shapes shows one essential drawback for this method: near the bands boundaries the are fast switching oscillation. Switching from one active band to another occurs with the frequency, which is defined by the simulation time step. This behavior is due to the fact, that identification process is dynamical too, and we should not neglect its dynamic.

The fig. 7, especially its right part, show us this approach is much more sensible to correct values of the identification system parameters itself, in particular $q_{\gamma}$.

The simulation results for the approach (9) shows (fig. 8-10), that this method shows best results among approaches under consideration. At least 2 models follows the object parameter, that gives good accuracy. Other models moved to extremum too, but continues to "patrol" working range.

\section{CONCLUSIONS}

In this paper an actual task for multi-model identifications system synthesis, analysis and defining condition for particular method selection is reached.

Results of identification process simulation allow us to make some conclusions:

- identification using models with fixed parameters, in spite of simplicity and speed, can not provide sufficient accuracy and full range covering;

- system with band-limited parameters gives better results, but suffer high frequency switching;

- system with models, which parameters displacement is described as body movement under forces gives best result;

- in conditions under consideration, there is no valuable difference between $p_{e g}$ and $p_{e l}$,

- every approach under consideration have own optimal value for the $q_{\gamma}$.

The practical value of this work is to provide both fast and precise methods for complex dynamic system identification, by which modern technological systems is characterized. Also, the results of this paper gives background to chouse correct method among considered.

\section{ACKNOWLEDGEMENTS}

This research was held under the bounds of the state budget thematic "Research and processes simulation of nonlinear dynamics formation of fractal structures functional coatings", registration number DR 0110 U003240.

\section{REFERENCES}

1. Moon F. C. Chaotic vibrations. An introduction for applied scientists and engineers / F. C. Moon. - Weinheim : Wiley-VCH Verlag $\mathrm{GmbH} \& \mathrm{Co}, 2004-310 \mathrm{p}$.

2. Анищенко В. С. Сложные колебания в простых системах. Механизмы возникновения, структура и свойства динамического хаоса в радиофизических системах / В. С. Анищенко. М. : Либроком, 2009. - 320 c.

3. Eykhoff P. System Identification Parameter and State Estimation / P. Eykhoff. - Wiley-Interscience, 1974. - 555 p.

4. Ljung L. System Identification: Theory for the User (2nd Edition) / L. Ljung. - Prentice Hall PTR, 1998. - 524 p.

5. Карабутов Н. Н. Структурная идентификация систем: Анализ динамических структур / Н. Н. Карабутов. - М. : МГИУ, 2008. $160 \mathrm{c}$.

6. Синхронизация регулярных, хаотических и стохастических колебаний: Учебное пособие [В. С. Анищенко, В. В. Астахов, Т. Е. Вадивасова и др.]. - М. : УРСС, $2008-144$ с.

7. Растригин Л. А. Случайный поиск в задачах оптимизации многопараметрических систем / Л. А. Растригин. - Рига : Зинатне, 1965. - $212 \mathrm{c}$.

8. Ивахненко М. М. Интегральный метод прямого поиска глобального экстремума / М. М. Ивахненко // Адаптивные системы автоматического управления. - 1980. - № 8. - С. 54-63.

9. Guda A. I. Criteria synthesis problem for the chaotic systems / A. I. Guda, A. I. Mikhalyov // Data Stream Mining \& Processing (DSMP): IEEE First International Conference, Lviv 23-27 August 2016: processings. - Lviv : IEEE, 2016. - P. 125-128.

10. Guda A. I. Multi-model methods and parameters estimation approaches on non-linear dynamic system identification / A. I. Guda, A. I. Mikhalyov // Regional interuniversity compendium of scientific works "System technologies". - 2016. - Vol. 2 (103). P. 57-62.

11. Guda A. I. Method of Lorenz systems parametric identification by the searching models ensemble / A. I. Guda, A. I. Mikhalyov / / Computer Sciences and Information Technologies. - 2015. Vol. 1. - P. 73-75.

12. Guda A. I. Multi-model identification system properties near extremum: simulations and analysis / A. I. Guda, A. I. Mikhalyov / / Journal of Applied Computer Science. - 2015. - Vol. 23, No. 2. P. 21-28.

Article was submitted 28.11.2016. After revision 05.12.2016.

Гуда А. И. ${ }^{1}$, Михалев А. П. ${ }^{2}$

${ }^{1}$ Канд. техн. наук, доцент, доцент кафедры информационных технологий и систем Национальной Металлургической академии Украины, Днипро, Украина

${ }^{2}$ Д-р техн. наук, профессор, зав. кафедры информационных технологий и систем Национальной Металлургической академии Украины, Днипро, Украина

СРАВНЕНИЕ МУЛЬТИМОДЕЛЬНЫХ МЕТОДОВ ИДЕНТИФИКАЦИИ В ЗАДАЧЕ ИДЕНТИФИКАЦИИ НИЛИНЕЙНЫХ ДИНАМИЧЕСКИХ СИСТЕМ

В статье рассмотрено несколько методов идентификации для нелинейных (возможно хаотических) динамических систем. Преимущества и недостатки существующих методов упоминаются. Все методы используют множество моделей. Предлагаются различные тактики для движения параметров модели с целью решения задачи идентификации. Простейшая тактика использует модели с фиксированными параметрами. Этот метод имеет простую реализацию, обеспечивают наилучшую скорость идентификации и худшую точность. Метод с моделями с ограниченной полосой поиска позволяет добиться большей точности, благодаря использованию моделей, настраивающий свой параметр в значение локального максимума, но подвержена высокочастотным колебаниям из-за игнорирования динамики самой системы идентификации. Подход с моделями, чье движение имитирует движение тела под действием внешних сил и вязкого трения демонстрирует минимальные ошибки идентификации и значительную скорость. Проведено моделирования процессов идентификации и сделаны выводы. Согласно результатам моделирования, выделены преимущества и недостатки. Выводы позволяют сделать правильный выбор в задаче выбора способа идентификации. Кроме того, результаты позволяют правильно выбрать некоторые параметры в системе идентификации. 
Ключевые слова: идентификация нелинейных динамических систем, мультимодельные методы идентификации, моделирование, оценивание экстремума.

Гуда А. І. ${ }^{1}$, Михальов П. І. ${ }^{2}$

${ }^{1}$ Канд. техн. наук, доцент, доцент кафедри інформаційних технологій і систем Національної Металургійної академії України (НМетАУ), Дніпро, Україна

${ }^{2}$ Д-р техн. наук, професор, зав. кафедри інформаційних технологій і систем Національної Металургійної академії України (НМетАУ), Дніпро, Україна

\section{ПОРІВНЯННЯ БАГАТОМОДЕЛЬНИХ МЕТОДІВ ІДЕНТИФІКАЦІЇ У ЗАДАЧІ ІДЕНТИФІКАЦІЇ НЕЛІНІЙНИХ ДИНАМІ-} ЧнИХ СИСТЕМ

У статті розглянуто кілька методів ідентифікації для нелінійних (можливо хаотичних) динамічних систем. Переваги і недоліки існуючих методів згадуються. Всі методи використовують множину моделей. Пропонуються різні тактики для руху параметрів моделі з метою розв'язання задачі ідентифікації. Найпростіша тактика використовує моделі з фіксованими параметрами. Цей метод має просту реалізацію, забезпечують найкращу швидкість ідентифікації і гіршу точність. Метод з моделями з обмеженою смугою пошуку дозволяє домогтися більшої точності, завдяки використанню моделей, які налаштовують свій параметр в значення локального максимуму, але схилено до високочастотним коливанням через ігнорування динаміки самої системи ідентифікації. Підхід з моделями, чий рух імітує рух тіла під дією зовнішніх сил і в'язкого тертя демонструє мінімальні помилки ідентифікації і значну швидкість. Проведено моделювання процесів ідентифікації і зроблені висновки. Згідно з результатами моделювання, виділені переваги та недоліки. Висновки дозволяють зробити правильний вибір в задачі вибору способу ідентифікації. Крім того, результати дозволяють правильно вибрати деякі параметри в системі ідентифікації.

Ключові слова: ідентифікація нелінійних динамічних систем, мультімодельні методи ідентифікації, моделювання, оцінювання екстремуму.

\section{REFERENCES}

1. Moon F. C. Chaotic vibrations. An introduction for applied scientists and engineers. Weinheim, Wiley-VCH Verlag GmbH \& Co, 2004, $310 \mathrm{p}$.

2. Anishhenko V. S. Slozhnye kolebanija v prostyh sistemah. Mehanizmy vozniknovenija, struktura i svojstva dinamicheskogo haosa v radiofizicheskih sistemah. Moscow, Librokom, 2009, $320 \mathrm{p}$.

3. Eykhoff P. System Identification Parameter and State Estimation. Wiley-Interscience, 1974, 555 p.

4. Ljung L. System Identification: Theory for the User (2nd Edition). Prentice Hall PTR, 1998, 524 p.

5. Karabutov N. N. Strukturnaja identifikacija sistem: Analiz dinamicheskih struktur. Moscow, MGIU, 2008, $160 \mathrm{p}$.

6. Anishhenko V. S., Astahov V. V., Vadivasova T. E. i dr. Sinhronizacija reguljarnyh, haoticheskih i stohasticheskih kolebanij: Uchebnoe posobie. Moscow, URSS, 2008, 144 p.
7. Rastrigin L. A. Sluchajnyj poisk v zadachah optimizacii mnogoparametricheskih sistem. Riga, Zinatne, 1965, 212 p.

8. Ivahnenko M. M. Integral'nyj metod prjamogo poiska global'nogo jekstremuma, Adaptivnye sistemy avtomaticheskogo upravlenija, 1980, No. 8, pp. 54-63.

9. Guda A. I, Mikhalyov A. I. Criteria synthesis problem for the chaotic systems, Data Stream Mining \& Processing (DSMP): IEEE First International Conference, Lviv 23-27 August 2016: processings. Lviv, IEEE, 2016, P. 125-128.

10. Guda A. I., Mikhalyov A. I. Multi-model methods and parameters estimation approaches on non-linear dynamic system identification, Regional interuniversity compendium of scientific works "System technologies", 2016,Vol. 2(103), pp. 57-62.

11. Guda A. I., Mikhalyov A. I. Method of Lorenz systems parametric identification by the searching models ensemble, Computer Sciences and Information Technologies, 2015, Vol. 1, pp. 73-75.

12. Guda A. I., Mikhalyov A. I. Multi-model identification system properties near extremum: simulations and analysis, Journal of Applied Computer Science, 2015, Vol. 23, No. 2, pp. 21-28. 